\title{
Negotiating Foreign Policy on the Domestic Front: Non-state Actors and Portuguese Colonialism
}

In the late 196os, as African governments began to single out Switzerland's connections with the white minority regimes of Southern Africa, protest also grew on the domestic front. Activist groups that developed out of the '1968' student movement and religious circles started to raise their voices against Portuguese colonialism and what was perceived as the Swiss government's complicity with a racist regime involved in a violent colonial war. These actors were part of a transnational protest network. In the late 196os, student movements in Western Europe and the US took up the issue of the unequal relations between the global North and the global South, proclaiming their solidarity with the peoples of the Third World. At the same time, some churches and religious actors, inspired by liberation theology, were increasingly engaged in political issues and started to criticise contemporary paternalistic approaches to development aid. Students, peace activists, intellectuals, radical leftist groups, and religious organisations formed a variety of solidarity movements with the Third World. The armed struggles of liberation movements in the global South motivated and sometimes radicalised these solidarity groups, and served as inspiration for a more general resistance against the capitalist system. ${ }^{1}$ In this context of growing mobilisation for Third World issues, the authoritarian Estado Novo regime, at the head of a colonial empire, was an ideal target.

Influenced by student protests against the wars in Vietnam and Biafra, numerous activist groups were created in Switzerland between 1967 and 1970. Although their aims and activities differed, they were united by their moral protest against injustice in the world. In their search for the causes of the unequal development of the North and the South, most activists focused on the responsibility of their own society. They aimed to inform people in Switzerland about the situation in the Third World and convince them of the need to break with the contemporary policies of industrialised countries that created structures of dependency in the global South. ${ }^{2}$ The Swiss government's role in the stabilisation of the Portuguese colonial empire was discussed as part of the broader critical analysis of North-South relations. This included

1 Kuhn, "Liberation Struggle and Humanitarian Aid", pp. 70-71.

2 Holenstein, Was kümmert uns die Dritte Welt, pp. 177-178. 
the reappraisal of aid and development policies and condemnation of the Third World's exploitation by the First World. As a result of this mobilisation, a wide range of non-state actors with very different motives joined with Swiss churches and missionary organisations, banks, and export firms in trying to influence the Swiss government's foreign policy in Southern Africa in parliament, through direct lobbying, and on the street. ${ }^{3}$

Although some Swiss activists had criticised the repressive nature of the Portuguese regime since the early 196os and an Anti-Apartheid Movement was founded in Geneva in 1964, it was not until the end of the decade that protest started to focus on Portugal's African colonies. In April 1968, the performance of a play that denounced Portuguese colonial rule and the complicity of Western countries and NATO caused a stir in Geneva and raised public awareness of the situation in Portugal and its colonies. The play enjoyed considerable success in Switzerland and abroad. ${ }^{4}$ In the following years, various Swiss individuals and groups showed much solidarity with the liberation struggles in Angola, Mozambique, and Guinea-Bissau and formed a heterogeneous protest landscape.

The solidarity group Medic'Angola, for example, initially focused exclusively on the liberation struggle in Angola and was based mainly in Zurich. Founded in 1970 or 1971 following contact between Swiss activists and MPLA members in Algiers, the group edited and sold a journal to inform the Swiss public about the situation in Angola. At the same time, its 10-25 members collected clothes, medicines, and money to be sent to the MPLA. In 1972, Medic'Angola drew closer to the Maoist inspired Swiss Communist Party and devoted itself to the anti-imperialist struggle and the class struggle in Switzerland. As a result of this radicalisation, several members left the group in late 1972 to found another movement, the Komitee Südliches Afrika (Southern Africa Committee, KSA). After Angola's independence, Medic'Angola changed its name to Kämpfendes Afrika (Fighting Africa), swapped its allegiance to UNITA to protest against the growing Soviet influence on the MPLA, and turned towards liberation movements in Rhodesia and South Africa. ${ }^{5}$ The group was in direct contact with

3 Some sections of this chapter are derived in part from Sabina Widmer, "Switzerland's Neutrality Policy in Southern Africa on the Defensive: The Swiss Government's Reactions to Non-State Actors' Solidarity with the Independence Struggles in the Portuguese Colonies, 1968-1974", Afriche e Orienti 19:3 (2017), pp. 101-114.

4 Nuno Pereira, "Le mouvement suisse de 1968 et le Portugal: de la dictature à la révolution (1962-1975)", in Schaufelbuehl, 1968-1978, pp. 147-16o, p. 151.

5 On Medic'Angola, see Marcel Dreier, "Afrikanische Befreiungsbewegungen und die antiimperialistische Solidaritätsbewegung in der Schweiz" in Schaufelbuehl, 1968-1978, pp. 161-176; Dag Henrichson, Registratur AA.5. The Archive of the Solidarity Group Medic'Angola / Kämpfendes Afrika (Zurich, 1971 - 1988), Basel: Basler Afrika Bibliographien. Namibia Resource Centre \& Southern Africa Library, 2002, pp. xix-xxv; Steinemann, Medic'Angola. 
African liberation movements and other European solidarity groups. In February 1974, for example, an MPLA representative visited the group to inform them about the independence struggle in Angola. ${ }^{6}$ A few weeks later, members of Medic'Angola participated in an international conference organised by a British solidarity group, together with activists from Austria, West Germany, Italy, and Denmark. On this occasion, the group held discussions with representatives of liberation movements, coordinated its activities with other movements, exchanged information and propaganda material, and visited the embassy of the PRC in London. ${ }^{7}$

The Anti-Apartheid Movement in Geneva, which became the Swiss AntiApartheid Movement in 1971 and created a branch in German-speaking Switzerland in 1975, also had international links. It exchanged pamphlets and information with the British Anti-Apartheid Movement. ${ }^{8}$ The Swiss AntiApartheid Movement, whose activities extended to all white minority regimes in Southern Africa, focused on information and lobbying in Switzerland. Its members grew from 450 in 1968 to 1,200 in 1975 . They included politicians, priests, and scientists. ${ }^{9}$ In Bern, Third World solidarity groups such as the Erklärung von Bern (Bern Declaration, EvB) and the Arbeitsgruppe Dritte Welt (Working Group Third World, $\mathrm{AG}_{3} \mathrm{~W}$ ), founded in 1968 by Protestant theologians and in 1969 by religious student groups, respectively, focused on Portuguese Africa within the framework of their general criticism of North-South relations. Both groups concentrated on activities in Switzerland and were key players in the Swiss campaign against the Cabora Bassa dam in Mozambique. ${ }^{10}$ $\mathrm{AG}_{3} \mathrm{~W}$ became the coordinating body of the Schweizerische Arbeitsgruppen für

No author [Medic'Angola], minutes, 26.o2.1974, Basler Afrika Bibliographien. Namibia Resource Centre \& Southern Africa Library (BAB), Basel, Switzerland, AA5.II.6.1o.

7 No author, "Bericht über die Osterkonferenz, Besuche in London und Paris", no date [between Easter 1974 and the Carnation Revolution], BAB AA5.II.I.I.1o.

8 See the correspondence between the British and the Swiss Anti-Apartheid Movements in the Bodleian Library in Oxford. In 1971, for example, two groups decided to exchange their journals: letter from Ethel de Keyser, Executive Secretary of the British Anti-Apartheid Movement, to C. Thommen, Geneva Anti-Apartheid Movement, 29.09.1971, and the attached letter from C. Thommen to the British Anti-Apartheid Movement, 15.09.1971, Bodleian Library, Oxford, UK, MSS AAM 1352.

9 Pereira, Anti-impérialisme et nouvelle gauche radicale, p. 42.

10 On the Erklärung von Bern (Bern Declaration, EvB), see Fischer, 'Die Solidarität in den Strukturen'; Anne-Marie Holenstein, Regula Renschler, Rudolf Strahm, Entwicklung heisst Befreiung. Erinnerungen an die Pionierzeit der Erklärung von Bern (1968-1985), Zürich: Chronos, 2008; Konrad Kuhn, "'Der Kampf der Entrechteten dort ist unser Kampf hier!' Entwicklungspolitisches Engagement und internationale Solidarität in der Schweiz", in Schaufelbuehl, 1968-1978, pp. 113-123; Manuel Schär, "Wie entwickeln wir die 'Dritte Welt'? Kontinuitäten und Brüche im Entwicklungsverständnis um 1968 in der Schweiz", in Schaufelbuehl, 1968-1978, pp. 99-111. 
Entwicklungspolitik (Swiss Working Groups for Development Policy, SAFEP), an umbrella organisation of about 30 Swiss groups that was officially constituted in January 1973 and focused on development policies. ${ }^{11}$ Churches, religiously motivated charities, trade unions, and members of parliament were also part of the Swiss protest landscape.

Their activities did not pass unobserved by either the Swiss or the Portuguese authorities. The files on different Swiss movements in the archives of the Portuguese secret service PIDE/DGS contain numerous pamphlets and Swiss newspaper articles. They show how closely the Estado Novo regime monitored 'anti-Portuguese' activities abroad. ${ }^{12}$ Swiss solidarity groups caused some irritation in Lisbon and sporadically led to complaints from Portugal. For example, in a discussion with the Swiss ambassador to Portugal in September 1968, the head of political affairs at the Portuguese foreign ministry, Gonçalo Caldeira Coelho, expressed his surprise that neutral Switzerland tolerated political debates concerning the internal affairs of third states and cited the doings of several solidarity groups in some detail. ${ }^{13}$ In response, the head of the Swiss Federal Police, André Amstein, briefed the DPA on these movements, commenting on their links to Angolan refugees living in Switzerland and to other radical organisations. Although he downplayed the influence of Swiss solidarity groups on public opinion, he mentioned repeatedly that the activists were part of the extreme left, thereby attempting to delegitimise their claims. As they were mostly Swiss, Amstein professed to be unable to intervene, but he promised to continue to monitor them. ${ }^{14}$ His response is symptomatic of the

11 Holenstein, Was kümmert uns die Dritte Welt, pp. 192-193; Fischer, "Die Solidarität in den Strukturen", pp. 35-37.

The Portuguese authorities reported, for example, on the formation of a Mouvement de soutien aux peuples de l'Angola et des autres colonies portugaises (support movement for the people of Angola and the other Portuguese colonies) in Geneva in July 1968 and on a solidarity pamphlet distributed by activists before Christmas 1970: PIDE Angola, report, "Informação no 784 - SC/CI (2). Movimento de apoio aos povos de Angola e das outras colónias portuguesas", 19.07.1968, ANTT, PIDE/DGS, Cl (2), no 4312, NT 7342; José de Vilhena Ramires Ramos, Serviços de Centralização e Coordenação de Informações de Moçambique (Mozambican Service for the Centralisation and Coordination of Information, SCCIM), report, "S.D.I. Apoios aos movimentos subversivos suiça; 'Action Noel 70", 20.05.1971, ANTT, SCCIM, no 648. The files on many Swiss activist groups such as the Afrika Komitee Basel (Africa Committee Basel) or the Groupe de travail Afrique australe et Portugal (Working Group Southern Africa and Portugal), Geneva, in the archives of the Portuguese secret service PIDE/DGS in the ANTT have not yet been declassified. of Police, "Umtriebe gegen Portugal in der Schweiz", 24.o9.1968, dodis.ch/32136. 
Swiss authorities' perception of a leftist threat to the state from within and provides some evidence of their comprehensive surveillance of unorthodox activities during the Cold War. ${ }^{15}$

In the late 196os and early 1970s, a number of key issues and events linked to Portugal's colonial policy polarised Swiss society and sparked conflict over foreign policy priorities between the Swiss government, civil society actors, and economic elites: arms exports to Portugal; the participation of Swiss firms and banks in the construction of the Cabora Bassa dam in Mozambique; the imprisonment of Mozambican Christians linked to the Swiss Mission; and Portugal's invitation as a guest of honour to the 1973 Comptoir Suisse trade fair.

\section{Neutrality, National Defence, and Humanitarianism: Arms Exports to the Third World}

Arms exports are a particularly sensitive issue for a neutral state. ${ }^{16}$ The Fifth Hague Convention of 1907 that determines the rights and duties of neutrals in war on land asserts that neutral states are not obliged to restrict arms exports to belligerents. If they do decide to impose restrictions or prohibitions, these must be impartially applied to all warring parties. ${ }^{17}$ Although Swiss arms exports to a belligerent are not prohibited by international law, there is a risk that the credibility and respectability of its neutrality would suffer if Switzerland were perceived to indirectly contribute to or even benefit from armed violence. In the late 1960s and early 1970s, arms sales to Third World countries not only had important ramifications on Switzerland's image as a neutral but the issue also divided Swiss society. The Swiss government was forced to juggle

15 On Swiss surveillance activities in the 2oth century, see Georg Kreis (ed.), Staatsschutz in der Schweiz. Die Entwicklung von 1935-1990. Eine multidisziplinäre Untersuchung im Auftrage des schweizerischen Bundesrates, Bern et al.: Paul Haupt, 1993.

16 On the tension between Swiss neutrality and arms exports, see notably Walther L. Bernecker, Thomas Fischer (eds.), Unheimliche Geschäfte. Schweizer Rüstungsexporte nach Lateinamerika im 20. Jahrhundert, Zurich: Chronos, 1991; Reto Moosmann, "Die Verwässerung des 'generellen Ausfuhrverbots' im Dienste von Armee und Rüstungsindustrie. Zur Kriegsmaterialausfuhrpolitik des Bundesrates in den 195oer und 6oer Jahren", Schweizerische Zeitschrift für Geschichte 56:2 (2006), pp. 152-167; Jean-Marie Pellaux, L'affaire Pilatus. Les milieux engagés et la Suisse officielle face aux exportations d'armes (1978-1985), Fribourg: Université de Fribourg, 2008.

17 "Laws of War: Rights and Duties of Neutral Powers and Persons in Case of War on Land (Hague V)", 18.10.1907, Yale Law School, The Avalon Project, Documents in Law, History and Diplomacy, http://avalon.law.yale.edu/2oth_century/hagueo5.asp (13 January 2021). 
the export and defence interests of Switzerland's arms industry, and the protest of religious and Third World organisations that considered arms exports incompatible with the country's humanitarian policy.

Until 1972, Swiss arms exports were regulated by the Decree of the Federal Council of 28 March 1949. This Decree confirmed the already existing general ban on the export of weapons and other so-called war materials. However, the Defence Technology Division (DTD) of the FMD, could, after consultation with the FPD, exceptionally grant export permits. Behind the scenes, the general ban on arms exports was softened almost immediately. The Swiss arms industry lobbied the Federal Council to liberalise its policy, arguing that exports were necessary to maintain the independent and technologically advanced armament industry that was essential for Switzerland's national defence. Many FMD members shared this view. ${ }^{18}$ In practice, a procedure was established whereby companies had to request permits both for the fabrication of specific war materials and for their export. Applications for export to countries where armed conflicts were taking place or threatened to break out were not to be granted. However, this restriction was treated rather flexibly. Thus, exports to warring parties might be authorised if there was a written guarantee that the arms delivered by Swiss firms would not be used in the conflict. ${ }^{19}$ Nevertheless, the Federal Council introduced export bans or restrictions for specific states and regions, notably Israel and the Arab countries in 1955, South Africa in 1963, and Rhodesia in $1965 .^{20}$

Applications for arms exports to Portugal presented a particular dilemma. On the one hand, the supply of arms to a NATO member country for its defence needs in Europe posed no political problems. It was in the interest of Switzerland's armament industry and considered essential for its national security. On the other, Portugal was undeniably an actor in the armed conflicts in its African colonies. From this angle, arms sales to Portugal were also contrary to UN policy. In the early 196os, both the UNGA and the Security Council requested its members and those of its specialised agencies to prevent the sale and supply to Portugal of arms and military equipment that might be used in the colonies. ${ }^{21}$ Although Switzerland was not a member of the UN, it was a member of the UN's specialised agencies. As it was politically inopportune to counter-

\footnotetext{
18 Moosmann, "Verwässerung des 'generellen Ausfuhrverbots", pp. 154-160.

19 David Gaffino, Autorités et entreprises suisses face à la guerre du Viêt Nam, 1960-1975, Neuchâtel: Alphil, 20o6, pp. 8o-81.

$20 \quad$ Moosmann, "Verwässerung des 'generellen Ausfuhrverbots", p. 162.

21 Resolution 1742 (XVI) of the UN General Assembly, "The situation in Angola", 11onnd plenary meeting, 30.01.1962, http://www.un.org/en/ga/search/view_doc.asp?symbol=A/ RES/1742(XVI) (13 January 2021); Resolution 180 (1963) of the UN Security Council, "Ques-
} 
act these resolutions and appear to benefit from armed conflicts in Southern Africa, the Swiss authorities wished to prevent Swiss-made arms from being used during the independence wars. The decision on whether to grant a permit to export arms to Portugal therefore hinged on whether the materials in question were likely to be used in Portuguese Africa.

This was often difficult to determine. The Swiss authorities did not always show uniform rigour when judging export applications. In 1964, the Federal Council refused arms manufacturer sig's project to supply rifles and guns to Portugal worth about CHF 20 million, as it would have been difficult to monitor their use. The Swiss authorities were also somewhat sceptical about the sudden Portuguese interest in the Swiss armament industry, as Portugal was not one of its traditional clients. Moreover, they suspected that the Portuguese government had turned to Switzerland since it had become more difficult to buy arms from NATO countries. ${ }^{22}$ When, five years later, the metal processing company Schweizerische Metallwerke Selve \& Co requested a permit for the fabrication of 65 tons of parts for the production of munitions destined for Portugal, the FPD insisted on a declaration by the Portuguese government that those munitions would not be used in the colonies. ${ }^{23}$ The department was not swayed by the argument that the opportunity to export their goods was essential to the Swiss company's survival. ${ }^{24}$ This demand proved too much for Selve's Portuguese business partner. It withdrew from the planned deal in mid-1969, stating that no Portuguese authority would be willing to meet such an unreasonable demand. ${ }^{25}$ In the same year, the export to Portugal of ten encryption units was authorised. In this case, the Portuguese Defence Department had signed a declaration that these units would not be re-exported. As their use in

tion relating to territories under Portuguese administration", 31.07.1963, http://www.un.org/ en/ga/search/view_doc.asp?symbol=S/RES/18o(1963) (13 January 2021). eral Councillor and head of the FPD, "Kriegsmateriallieferungen nach Portugal", 31.01.1964, p. 3, dodis.ch/31455.

23 Letter from Jacques-Bernard Rüedi to the Directorate of the Federal Military Administration (DFMA), "Ausfuhr von Kriegsmaterial nach Portugal", 31.03.1969, SFA E20o1E\#1980/ $83^{\#} 3784^{*}$.

24 Letter from the firm Schweizerische Metallwerke Selve \& Co to the DFMA, "Ausfuhr von Kriegsmaterial nach Portugal", 23.01.1969, p. 1, SFA E2001E\#1980/83\#3784*.

25 Cited in the letter from the Schweizerische Metallwerke Selve \& Co to the Board of Control for Trade in War Materials of the DFMA, "Ausfuhr von Kriegsmaterial nach Portugal", 02.07.1969, attached to the letter from Jean-Louis Grognuz, Board of Control for Trade in War Materials, to the DPA, "Ausfuhr von Näpfchen nach Portugal", 04.07.1969, SFA E2001E\#1980/83\#3784*. 
the colonies was therefore "although not excluded, at least unlikely", the FPD granted the export permit. ${ }^{26}$

While the federal administration's control over the final destination of arms exports to Portugal was not watertight, sales of war materials authorised by the FPD did not reach significant amounts. An overview of Swiss arms exports to Portugal between 196o and 1970 shows that they hardly ever exceeded CHF 0.3 million per year and consisted mainly of encryption units. Exceptionally, in 1961 and 1972 , they reached CHF 0.6 million. ${ }^{27}$ It is possible that subsidiaries of Swiss firms in other European countries might have delivered arms to Portugal, but such deals left no traces.

There are no signs that Swiss arms were exported to the liberation movements in Angola and Mozambique. The FPD stood firm when it came to arms sales to states bordering the Portuguese colonies. In August 1968, the department refused the export of a cannon to Zambia because of the country's tense relations with neighbouring Rhodesia, which was on Switzerland's embargo list, and the activities of Zambia-based Rhodesian and Mozambican liberation movements. ${ }^{28}$ Through the Swiss embassies in London and Nairobi, Zambian officials unsuccessfully urged Bern to reconsider. ${ }^{29}$ While Bern was at least in some cases willing to give the authoritarian Estado Novo regime the benefit of the doubt and allow limited arms sales to Portugal in the hope that the material would not be used in the colonies, it did not extend the same courtesy to the Zambian government in the middle of 1968.

In the late 196os, a case of illegal arms sales to Third World states caused the so-called Bührle scandal and led to the reorganisation of Swiss legislation on arms exports. In late 1968, it was made public that the Swiss arms manufacturer Oerlikon Bührle had deliberately sold arms to seven embargoed countries, including South Africa, by supplying falsified end user certificates to the Swiss authorities. This affair caused a huge public outcry. The use of Bührle air defence guns by the Nigerian government during the civil war, at the same time as the ICRC, supported by the Federal Council, coordinated an important

26 Note from Michael Gelzer, deputy chief of the DPA, to Willy Spühler, Federal Councillor and head of the FPD, "Ausfuhr von Kriegsmaterial nach Portugal", 29.08.1969, and notes attached to this document, SFA E2001E\#1980/83\#3784*. Jean-Louis Grognuz, table, "Exportations de matériel de guerre en francs, Portugal 19601970", 25.08.1971, SFA E2001E-o1\#1982/58\#6106*; Grognuz, table, "Entwicklungsländer. Export von Kriegsmaterial 1972", 07.04.1973, SFA E5001G\#1985/220\#1110*.

28 Letter from Michael Gelzer to Oerlikon Bührle, "Ausfuhr einer 20 mm-Kanone und von Munition dazu nach Zambia", 16.08.1968, SFA E5001G\#1982/18\#2738*.

29 Letter from Michael Gelzer to the Swiss Embassy in Kenya, "Waffenausfuhr nach Zambia", 07.02.1969, SFA E5001G\#1982/18\#2738*. 
relief mission and the Swiss population made large donations in support of the starving population of the secessionist province of Biafra, outraged many people. The scandal provoked several parliamentary questions and led to the criminal prosecution of the director and high-ranking employees of Oerlikon Bührle and their conviction in November 1970. In the second half of 1968, Swiss peace activists launched a popular initiative to prohibit all arms exports with the exception of those to neutral European states. Members of Swiss churches, charities, development organisations, trade unions, and radical youth groups rallied behind the initiative. ${ }^{30}$

In the aftermath of the Bührle scandal, the federal administration also started to review Switzerland's policy on arms exports. The Federal Council even considered imposing an embargo on arms exports to the entire African continent. The government set up an interdepartmental working group to discuss the issue. Considering that Swiss exports to African countries were limited and the major potential sales markets South Africa and the Arab countries were already embargoed, the working group judged that an extension of the embargo to the whole African continent would not have serious consequences for the Swiss armament industry. A total embargo, such as that practised by Sweden, could also be justified from a political point of view, as Federal Councillor Willy Spühler explained in his proposal to the Federal Council in May 1969: "Indeed, the problem of deliveries of war materials to countries that benefit from development aid and that periodically need humanitarian assistance is in no part of the world as severe as in Africa. The example of Nigeria/Biafra shows this very clearly."31 However, the working group feared that an embargo on a whole continent might create an unwelcome precedent. The public might then argue that embargoes should also be introduced on Asia and Latin America, "where upheavals and revolutions also tend to happen periodically" and where an embargo would have "much more serious consequences for our

30 On the Bührle scandal, see Kalt, Tiersmondismus in der Schweiz, pp. 354-40o; Ruedi Tobler, "Wenn Schweizer Kanonen auf IKRK-Flugzeuge schiessen. Der Bührle Skandal", in Heinz Looser et al. (eds)., Die Schweiz und ihre Skandale, Zürich: Limmat Verlag, 1995, pp. 93-106; with a focus on the Biafra conflict, Dominik Matter, "'sos Biafra.'Die Schweizerischen Aussenbeziehungen im Spannungsfeld des nigerianischen Bürgerkriegs 19671970", Bern: Diplomatische Dokumente der Schweiz (DDS), 2015, pp. 46-49; 90-95; Gian-Luca Stössel, Kriegsmaterial und Solidarität - Die Schweiz und der Biafrakrieg. Die Bemühungen der Schweiz um Linderung der humanitären Auswirkungen des Biafrakriegs und die Bührle-Affäre, Saarbrücken: vDM Verlag Dr. Müller, 2011.

Willy Spühler, proposal to the Federal Council, "Kriegsmaterialausfuhr nach Afrika, Indien und Pakistan", confidential, 22.05.1969, p. 2, attached to the excerpt of the minutes of the Federal Council's meeting on 2 June 1969, "Kriegsmaterialausfuhr nach Afrika, Indien und Pakistan", SFA E5001G\#1982/19\#2509*. 
industry". ${ }^{32}$ In the end, this economic argument won the day. In June 1969, the Federal Council only prohibited the export of arms to specific African countries. Included in the embargo were the Portuguese colonies and neighbouring states: Tanzania, Zambia, Zaire, and Guinea. ${ }^{33}$

While the Swiss government embargoed Angola, Mozambique, GuineaBissau, and their bordering countries to prevent Swiss-made arms from reaching the liberation movements, it continued to allow limited arms exports to Portugal despite the remaining risk that the material might be used in its colonies. Although there was no absolute guarantee that arms sold to Portugal would not end up in the colonies, the Swiss government was willing to take the risk of selling to only one warring party and thus to violate Switzerland's neutrality.

In June 1972, the Swiss parliament adopted a new federal law on war materials. It prohibited arms exports to certain countries if they compromised Switzerland's policy on human rights and its humanitarian and development aid. Three months later, the Swiss people rejected the initiative for the ban of arms exports in an extremely tight vote. ${ }^{34}$ The FPD and the FMD subsequently reviewed a number of applications for export permits to Portugal. Due to the Estado Novo regime's colonial policy and the violation of human rights in Portuguese Africa, the two departments demanded, in a proposal to the Federal Council, stricter control of the Portuguese written guarantees that the arms would not be used in the colonies. They were well aware that this position was not consistent: "An export ban would be more correct."35 But, as Portugal was a fellow EFTA member and close trading partner of Switzerland, the departments suggested granting export permits for arms that had already been commissioned, but refusing all new requests for the production of war materials for Portugal. The Federal Council finally decided to end the unequal treatment of the belligerents in the independence wars in Portuguese Africa by agreeing to gradually phase out arms exports to Portugal in November $1972 .{ }^{36}$ The

$32 \quad$ Ibid., p. 3 .

33 Excerpt of the minutes of the Federal Council's meeting on 2 June 1969, "Kriegsmaterialausfuhr nach Afrika, Indien und Pakistan", confidential, SFA E5001G\#1982/19\#2509*.

34 Walter Kälin, "Schweizerische Kriegsmaterialausfuhr im Spannungsfeld von Menschenrechten und Entwicklungszusammenarbeit", in Bernecker, Fischer, Unheimliche Geschäfte, pp. 73-91, p. 74 .

FMD, FPD, proposal to the Federal Council, "Richtlinien für die Behandlung von Fabrikations- und Ausfuhrgesuchen für Kriegsmaterial im Anschluss an die Volksabstimmung vom 24. September 1972", 29.11.1972, p. 16, SFA E2001E-o1\#1982/58\#6106*.

36 Decree of the Federal Council, "Richtlinien für die Behandlung von Fabrikations- und Ausfuhrgesuchen für Kriegsmaterial im Anschluss an die Volksabstimmung vom 24. September 1972", 15.11.1972, SFA E2OO1E-o1\#1982/58\#6106*. 
Swiss government hoped that this would discreetly stop future arms sales to the Estado Novo regime. The introduction of an embargo was to be avoided, as it might have been construed as a public condemnation of Portugal's colonial policy, which could have irritated Lisbon and threatened Swiss trade with the country.

The Bührle scandal mobilised a heterogeneous coalition of Swiss non-state actors sympathetic to Third World issues. It launched a debate on weapons sales to Third World countries that led to a tightening of Switzerland's legislation on arms exports in 1972. The possible participation of Swiss firms in the construction of the Cabora Bassa dam in Mozambique was another mobilising factor for Switzerland's civil movement for solidarity with the Portuguese colonies.

\section{Colonial Exploitation, Business Interests, and State Export Promotion: The Cabora Bassa Dam}

For the people of Mozambique, it does not matter whether the dam is to be built by British and Swiss, by Americans and French or by West Germans, Swedes and South Africans. [...] The involvement of foreign capital in Cahora Bassa and any other scheme in Mozambique is a hostile act against the people of Mozambique. ${ }^{37}$

Ever since the beginning of the construction of the huge Cabora Bassa dam and hydroelectric power plant on the Zambezi River in Mozambique in 1969, the Mozambican liberation movement FRELIMo had denounced the project as a means of perpetuating white minority rule in Southern Africa and it had attacked the construction site. The fact that the electricity generated in this power plant was mainly intended for South Africa supported FRELIMO's claims. It was also argued that the dam would be used to attract large numbers of white settlers. Independent African governments, the OAU, and the WCC supported FRELIMO's struggle against Cabora Bassa. Several UN resolutions also condemned the project. Cabora Bassa was an important focal point for groups opposed to Portuguese colonialism in many Western European states. The dam was planned by Portuguese engineers, financed to a large degree by South Africa, and slated for construction by a consortium of West German, French, Italian, Swedish, South African, and Portuguese firms. It was to be

37 Emphasis in original. No author, "Caetano, Capitalism, Cahora Bassa", Mozambique Revolution 40 (September 1969), pp. 4-12, p. 11. 
the largest in Africa and the fifth largest in the world at that time. Numerous solidarity and Third World movements in Western Europe took up the issue, criticising the firms participating in the dam's construction for supporting the Portuguese Empire. ${ }^{38}$

Although in 1966 the Swiss trade authorities had hoped that the Cabora Bassa dam would provide good opportunities for Switzerland's export industry, by early 1968 big firms, such as Sulzer and Escher Wyss, had withdrawn from the project for technical reasons. ${ }^{39}$ However, one of the German participants in the Zamco consortium charged with the construction of the dam, в вс Mannheim, was a subsidiary of ввс Baden. ${ }^{40}$ ввс Baden acted as a subcontractor of its subsidiary and delivered electrical supplies destined for Cabora Bassa. There are indications of other Swiss firms' or banks' involvement in the Cabora Bassa project, but no accurate information is available. ${ }^{41}$ As ввС Baden's deliveries destined for a project that was seen by many as a symbol of Portuguese colonial oppression were known at the time, the firm was an obvious target for protest. The emerging Swiss protest movement focusing on Portuguese colonialism rallied round the Cabora Bassa campaign, ${ }^{42}$ thereby answering the OAU Council of Ministers' call of early 1970, "on all progressive people the world

38 For a detailed contemporary analysis of the Cabora Bassa project, see Keith Middlemas, Cabora Bassa. Engineering and Politics in Southern Africa, London: Weidenfeld and Nicolson, 1975. See also Kuhn, "Liberation Struggle and Humanitarian Aid"; Lopes, West Germany and the Portuguese Military Dictatorship, pp. 74-76; Sellström, Sweden and National Liberation in Southern Africa. Volume I: Formation of a Popular Opinion, pp. 484-503.

39 See the letter from the Trade Division to the Vorort and the Verein Schweizerischer Maschinen-Industrieller (Swiss Association of Machinery Manufacturers, vSM), "Moçambique - Zambesi-Projekt", o6.04.1966, Archiv für Zeitgeschichte (Archives for Contemporary History, AfZ), Zurich, Switzerland, Ів Vorort-Archiv, 377.20.1; letter from the Trade Division to the Vorort and the vsm, "Mozambique - Zambesi-Projekt", 12.10.1966, ibid., and the attached letter from Jakob Etter, Swiss consul in Mozambique, to the Trade Division, "Moçambique - Zambesi-Projekt", 30.o9.1966; letter from René Naville, Swiss ambassador in Portugal, to the Trade Division, 15.03.1968, pp. 2-3, SFA E7110\#1979/14\#1638*.

40 ввс Baden participated to $56.6 \%$ in its German daughter: Kuhn, "Kampf der Entrechteten", p. 117 .

41 In 1970, the Swiss embassy in Lisbon reported that the Zurich firm Holding Rodio indirectly participated in the Cabora Bassa project. Three years later, activists cited a newspaper report according to which big Swiss banks had, in summer 1971, covered a CHF 50 million bond of the South African government destined for the construction of the dam: telegram no 12 from the Swiss embassy in Lisbon to the FPD, 22.06.1970, SFA E20o1E\#1980/83\#3430*; ciscop, Suisse-Portugal, p. 78.

42 This point is made by Fischer, 'Die Solidarität in den Strukturen'; Holenstein, Was kümmert uns die Dritte Welt, pp. 188-189; Holenstein, Renschler, Strahm, Entwicklung heisst Befreiung; pp. 50-52; Kuhn, "Kampf der Entrechteten", pp. 118-121. 
over to rise and condemn the actions of the governments of their countries involved in the execution of this diabolical project."43

Swiss opposition to Cabora Bassa emerged in June 1970. Private visits by the South African Prime Minister to Geneva and the Minister of Finance to Bern and Zurich led solidarity groups to suspect that Swiss capital would participate in the construction of the dam. ${ }^{44}$ On 10 June 1970, Jean Ziegler, a social democratic member of the Swiss National Council and Professor of Sociology at the University of Geneva, addressed a parliamentary question to the Federal Council. He asked the government to prevent Swiss firms from participating in the construction of the dam. ${ }^{45}$ In the following weeks and months, numerous organisations, including student groups, the Christian Peace Service, and the Anti-Apartheid Movement in Geneva, took up the call. They insisted that the government should, at the very least, refrain from supporting the construction of the dam by granting ERGs to Swiss firms. ${ }^{46}$ As two student movements at the University of Bern wrote to the Federal Council in June 1970, "a Swiss intervention at this point would appear in a bad light, coming across as unscrupulous stop-gapping. We urge you to do everything in your power to prevent capital interests, rather than humanitarian principles, from determining Swiss foreign policy again." ${ }^{47}$ The Schweizerische Evangelische Kirchenbund (Federation of Swiss Protestant Churches, SEK), which could scarcely be accused of

43 Declaration CM/St. 3 (XIV) of the OAU Council of Ministers' 14th Ordinary Session from 27 February to 6 March 1970, "Declaration on the Cabora Bassa Hydro-Electric Dam by the Fourteenth Ordinary Session of the OAU Council of Ministers", https://au.int/sites/ default/files/decisions/9596-council_en_27_february_6_march_1970_council_ministers_ fourteenth_ordinary_session.pdf (13 January 2021).

44 Kuhn, "Kampf der Entrechteten", p. 117.

45 National Council, "Petite question Ziegler du 10 juin 1970. Barrage de Cabora Bassa - Participation suisse", attached to the excerpt of the minutes of the Federal Council's meeting on 9 September 1970, SFA E2001E\#1980/83\#3430*.

46 See, for example, the open letter from the Arbeitsgruppe Angola (Angola Working Group) and the Arbeitsgruppe für Kirche und Gesellschaft der Unversitätsgemeinden Bern (Church and Society Working Group of the University of Bern), to the Federal Council, 13.06.1970, SFA E7110\#1981/41\#1776*; letter from Hedwig Meyer-Schneeberger, Christian Peace Service and Fonds für Entwicklung und Partnerschaft in Afrika (Fund for Development and Partnership in Africa), to the Federal Council, "Besuch von Ministerpräsident Vorster und schweizerische Beteiligung am Projekt von Cabora Bassa”, 23.06.1970, pp. 3-4, dodis. $\mathrm{ch} / 35939$; letter from the Committee of the Anti-Apartheid Movement in Geneva to the Federal Council, 25.06.1970, SFA E2001E\#1980/83\#3430*; open letter from the Tagelöhner für die Dritte Welt (Day Labourers for the Third World) to the Federal Council, 17.10.1970, ibid.

47 Open letter from the Angola Working Group and the Church and Society Working Group of the University of Bern to the Federal Council, 13.06.1970, SFA E7110\#1981/41\#1776*. 
left-wing tendencies, also urged the Swiss government to consider political and developmental aspects when taking a position on Cabora Bassa. ${ }^{48}$

The question of whether or not an ERG should be granted for deliveries destined for Cabora Bassa is particularly salient, as it highlights the conflicts between Third World solidarity, economic interests, and foreign policy. The issue had first arisen in October 1969. Representatives of ввС Baden met with the Vice-Director of the Trade Division, Hans Bühler, to enquire about the possibility of obtaining an ERG cover amounting to Deutschmark 6o million (CHF 70.2 million). Bühler informed the firm that this demand could only be considered if the sum was considerably reduced. Switzerland's limited annual exports to Mozambique did not justify such a significant financial engagement. ${ }^{49} \mathrm{He}$ did not comment on the legitimacy of the Cabora Bassa project. The DPA was not consulted at this stage. According to an internal document of ввс Baden dated January 1971, the parent company's deliveries to its German subsidiary amounted to CHF 25 million, CHF 11 million of which were covered by the German Hermes insurance. ${ }^{50}$ Historian Konrad Kuhn argued that this partial cover, coupled with the fear of additional negative publicity, explains why в ВС Baden never officially applied for an ERG cover in Switzerland. ${ }^{51}$ The absence of such a demand saved the Swiss authorities from a trade-off between the wish to support Switzerland's economy, and the risk to the country's image if the Swiss government was perceived to actively support firms that contributed to the stabilisation of colonial rule in Mozambique.

Confronted with Ziegler's parliamentary question and protest letters from solidarity movements, the DPA's first priority was to gain more information about the issue. The directorate therefore requested Swiss embassies in states where firms were or had been involved in the construction of Cabora Bassa to report on their host governments' and the local populations' attitude towards the project. ${ }^{52}$ The replies showed that, while the Swedish firm

48 Letter from W. Sigrist and W. Probst, sEK, to the Federal Council, "Cabora Bassa-Projekt", o8.07.1970, SFA E2001E\#1980/83\#3430*.

49 Note from AE to Ernst Henri Léchot, responsible for relations with Portugal within the Trade Division, "Anfrage von Herrn Nationalrat Jean Ziegler vom 10.6.1970 wegen allfälliger schweizerischer Lieferungen für den Bau des Staudammes von Cabora Bassa (Mozambique)", 17.06.1970, p. 1, SFA E7110\#1981/41\#1776*. The sum has been converted to CHF using the exchange rates indicated in table O.22a of the Hsso database, "Wechselkurse für Sichtdevisen in der Schweiz 1875-1907 und 1913-1992 (in Franken)”.

5 [?] Bernhardt, [?] Rinderknecht, ввс, memorandum, "Information über Cabora Bassa", p. 11, 07.01.1971, SFA E2001E-01\#1982/58\#440*.

$5^{1} \quad$ Kuhn, “Kampf der Entrechteten”, p. 118.

52 Telegram from the FPD to the Swiss embassies in the FRG and France, 18.06.1970, p. 2, SFA E2001E\#1980/83\#3430*; telegram from the FPD to the Swiss embassies in the UK, Sweden 
ASEA had renounced its participation in the Zamco consortium because of parliamentary and governmental pressure, the positions of British and Italian firms were less clear-cut. Although Rome kept its distance from Cabora Bassa, an Italian firm participated in the project. According to the FCO, British nonparticipation was entirely due to commercial factors. ${ }^{53}$ Reassured that governmental condemnation of the project was the exception in Western Europe, different offices in the FPD and the FDEA collaborated to edit the Federal Council's reply to Ziegler's question. This was published in September 1970. The reply did not enter into moral or political considerations. It hinted that the project would be beneficial for the African population and independent Malawi, not only for European settlers. It contained the same arguments that had already been advanced in reply to different solidarity groups: the eventual participation of Swiss firms or banks would not be decisive for the realisation of the project; the federal authorities had no legal means to prevent Swiss firms from participating; and if an ERG cover were to be solicited, the Federal Council would examine the application with care. ${ }^{54}$

It is impossible to know how BBC Baden's directors would have reacted if the Swiss government had insisted on the firm's withdrawal from the Cabora Bassa project. It is true that a few years later, in early 1974, ввС abandoned its plans to tender for a contract to build a power station in Rhodesia after considerable pressure from the Swiss trade authorities. ${ }^{55}$ But in the Rhodesian case, the firm's activities would have been much more exposed than in the case of Cabora Bassa, where ввс's contribution was small and the Portuguese government still enjoyed a certain degree of international legitimacy.

In reaction to the mounting pressure from grassroots activists and some church publications, ввС's leaders prepared to justify their participation in the construction of the dam. In late 1970, BвC representatives participated in

and Italy, 18.o6.1970, p. 2, ibid.; telegram from the FPD to the Swiss embassies in Portugal and South Africa, 18.06.1970, p. 2, ibid.

53 Telegram no 85 from the Swiss embassy in Sweden to the FPD, 19.06.1970, SFA E2001E\#1980/83\#3430*; telegram no 57 from the Swiss embassy in Portugal to the FPD, 23.06.1970, p. 2, ibid.; telegram no 157 from the Swiss embassy in Italy to the FPD, 23.06.1970, ibid.; letter from René Keller, Swiss ambassador in the UK, to the DPA, "Cabora Bassa", 24.06.1970, p. 2, ibid.; note from Philippa Drew, CSAD, to [?] Budgen, FCo, "Cabora Bassa", 23.06.1970, TNA FCO 45/523.

54 "Réponse du Conseil federal", attached to the excerpt of the minutes of the Federal Council's meeting on 9 September 1970, SFA E2001E\#1980/83\#3430*.

55 Note from Fritz Rothenbühler, Delegate of the Federal Council for Trade Agreements, to Ernst Brugger, Federal Councillor and head of the FDEA, "Rhodesien - Kraftwerkprojekt der ввс. Schreiben von Herrn A. Schärer, Greifensee, vom 5. Februar 1974”, 14.03.1974, SFA E7110\#1985/97\#1755*. 
panel discussions with solidarity groups. In January 1971, the firm prepared a long document for their own staff to help them refute frequently advanced criticisms. The document focused mainly on the civilising merit of the dam project. It also aimed to discredit the activists by emphasising their Communist sympathies. ${ }^{56}$ Finally, в вС publicly downplayed its involvement in the project; the firm only mentioned the part of its deliveries covered by the German Hermes insurance. ${ }^{57}$

In the following years, student, religious, and Third World groups continued to organise information events, publish articles, distribute pamphlets, and lobby the Federal Council. They exchanged materials with activists in other countries and maintained contact with representatives of African liberation movements. Despite the significance of the campaign against Cabora Bassa, Swiss protest remained limited when compared to the situation in the FRG. In a meeting in February 1972, ввС Baden's directorate noted that agitation against Cabora Bassa had reached such levels in West Germany that the firms involved in the dam's construction had had to take coordinated countermeasures. There was no mention of further steps to be taken in Switzerland. ${ }^{58}$ In the FRG, demonstrations were attended by up to 1,00o people and there were clashes with the police. Some German activists even acquired shares in the companies involved in the building of Cabora Bassa and condemned the project at shareholder meetings. In response, German companies employed public relations firms to defend their actions, collaborated with economic associations, and lobbied the Brandt government to maintain its commitment to the project..$^{59}$ The Swiss campaign against Cabora Bassa lost its momentum in early 1973, when the invitation of Portugal to the Comptoir Suisse trade fair provided the solidarity movements with a new target. After the Carnation Revolution and Mozambique's independence, work on the dam continued without much interruption. It was finally completed in $1979 .{ }^{60}$

The French ambassador in Switzerland, Jacques Roux, had noted in June 1970 that the nascent controversy surrounding Cabora Bassa was a sign that "some Swiss minorities are starting to realise that their country's image in the

56 [?] Bernhardt, [?] Rinderknecht, ввс, memorandum, "Information über Cabora Bassa", 07.01.1971, SFA E2OO1E-o1\#1982/58\#440*.

57 Kuhn, "Kampf der Entrechteten", pp. 117-118; see also Hans Bühler, Vice-Director of the Trade Division, memorandum, "Caborah Bassa", 19.01.1971, SFA E7110\#1982/108\#1341*.

$5^{8}$ [?] Dietrich, ввс Baden, minutes of the 21 meeting of the directorate (DS-CH) of 24 February 1972, no date, p. 3, Historical Archives Авв (НААвв ), Baden, Switzerland, file 6о5610.

59 Lopes, West Germany and the Portuguese Military Dictatorship, pp. 67, 75-76.

6о Minutes of the meeting of ввс's Board of Directors on 18 November 1975 in Baden, no date, p. 19, НААвв, folder 253689, file 6о5626; Kuhn, “'Kampf der Entrechteten”, p. 120. 
world depends less on generous but vague declarations of intent than on the specific attitude it adopts towards certain problems that international conscience has to face." He was convinced, however, that the protest would have no noticeable effect on the Swiss government and business elites. ${ }^{61}$ Roux was partially right. Grassroots protest against the Cabora Bassa project did not lead ввС Baden to withdraw from delivering electrical supplies to its subsidiary, nor did it change the Swiss government's position. It did, however, raise public awareness of Western firms' activities in colonial Mozambique. The campaign also provided a rallying point for protest movements and probably strengthened their international networks.

A Question of (Non-)Interference: The Swiss Mission's Efforts to Free Mozambican Church Members

While the construction of the Cabora Bassa dam mobilised activists and churches in many Western European states, in Switzerland solidarity with arrested Mozambican Christians was mostly limited to Protestant circles in the French-speaking part of the country. In June 1972, the Portuguese secret service PIDE/DGS arrested over 1,500 Mozambicans suspected of being members of FRELIMO. Among the detained were approximately 3 o members of the African sister church of the Swiss Mission. In the following years, Swiss missionaries made significant efforts to secure the release of their African church members and to allay Portuguese suspicions that they were collaborating with FRELIMO. This issue sheds light on the role of churches and missionary organisations in colonial Mozambique and underlines their importance to the Swiss government's foreign policy in sub-Saharan Africa.

In colonial Mozambique, the Catholic Church was an important pillar of the Portuguese regime. In return for stabilising the colonial system through the evangelisation and education of the African population, the Catholic hierarchy and missions benefited from state subsidies and tax advantages. Compared to Protestant missionary societies, they enjoyed a privileged situation. In the 196os, and especially after Pope Paul Vi received leaders of frelimo, the MPLA, and the PAIGC in July 1970, divisions opened up within the Portuguese Catholic Church. Some Catholic priests in Mozambique took a stand

61 Letter from Jacques Roux, French ambassador in Switzerland, to the French foreign minister, "Du passage du Premier Ministre de la République d'Afrique du Sud", 30.o6.1970, p. 4, CADN 89PO/2002021/66o. 
against the colonial regime. ${ }^{62}$ Unlike their Catholic counterparts, Protestant missions - and the Swiss Mission in particular — have often been described as supporters of Mozambican independence. Teresa Cruz e Silva, for example, underlined the Swiss Mission's important contribution to shaping the political consciousness of its African church members and educating Mozambique's future elites ${ }^{63}$ However, Eric Morier-Genoud and Sérgio Inácio Chichava criticised this dominant view of the Swiss Mission's exceptionalism. They underlined the contributions of other Protestant and Catholic missionary societies in the formation of Mozambican nationalism and the diversity of positions within the Catholic Church. ${ }^{64}$

Swiss Protestant missionaries first arrived in Mozambique in the late nineteenth century. After the Second World War, the Swiss Mission, which was also active in South Africa, was increasingly Africanised. In 1962, the Swiss missionaries concluded an accord with the Igreja Presbiteriana de Moçambique (Presbyterian Church of Mozambique, IPM) signing over to the latter the responsibility for the missionary, educational, and humanitarian works of the former Swiss Mission. Protestant churches in French-speaking Switzerland created the DM, which continued to provide funding and aid to the IPM and remained the only interlocutor recognised by the Portuguese authorities. ${ }^{65}$ The DM had close relations with the African population and with members of FRELIMO. The founder and first president of FRELIMO, Eduardo Mondlane, was a former pupil of a Swiss missionary school and remained in friendly contact with some missionaries until his assassination in $1969 .{ }^{66}$ Ever since the outbreak of the independence war in 1964, the Catholic colonial authorities were wary of these contacts. The suspicion that Protestants were inciting the Mozambican people to insurrection was also fuelled by the Programme to Combat Racism that the ecumenical wCC launched in 1970 after two years of planning. The programme focused on Southern Africa and distributed funds to liberation movements, including FRELIMO. ${ }^{67}$

62 See Amélia Neves de Souto, Caetano e o Ocaso do 'Império'. Administração e Guerra Colonial em Moçambique durante o Marcelismo (1968-1974), Porto: Edições Afrontamento, 2007, pp. 383-413.

63 Cruz e Silva, Protestant Churches, p. 154. For a critical discussion of the literature on the church in Mozambique, see Chichava, "Unlike the Other Whites?"; Eric Morier-Genoud, The Catholic Church, Religious Orders and the Making of Politics in Colonial Mozambique: The Case of the Diocese of Beira, 1940-1974, Ann Arbor: Um I, 2006, pp. 29-36.

64 Chichava, "Unlike the Other Whites?"; Morier-Genoud, The Catholic Church, pp. 316-317.

65 Cruz e Silva, Protestant Churches, p. 135.

66 On the relations between Eduardo Mondlane and the Swiss Mission, see ibid., pp. 101-119.

67 The Programme to Combat Racism started a bitter controversy in Switzerland and led to the first public discussion of the country's position towards South Africa and Apartheid: Jeannerat, Morier-Genoud, Péclard, Embroiled, pp. 214-215. 
Prompted by Portuguese suspicions of their subversive role in Mozambique, the colonial regime's increasing repression against the African population, and the announcement of the Programme to Combat Racism, in the late 196os the DM started to reconsider its presence in Mozambique. The emerging Third World solidarity movement in Switzerland probably also contributed to this reconsideration. At the missionary Synod in June 1969, some delegates called for the withdrawal of Swiss missionaries from Mozambique and South Africa in order to avoid being associated with the white minority regimes. However, the Synod finally voted for the DM to continue activity in Southern Africa in support of its local sister churches. ${ }^{68}$ The WCC's decision, in August 1970, to support FRELIMO financially sparked further discussions. In October of the same year, in an internal position paper, the DM stated its opposition to racism and colonial oppression. The authors expressed their desire for Swiss churches to take a clear and courageous stand and incite the Swiss population to oppose racism in Southern Africa. With regard to their own role, however, they argued for discretion, so as not to endanger African church members and Swiss missionaries: "Our responsibilities and direct relations with the South African and Mozambican churches sometimes require the DM to be silent here about what we know and do, in order to still be able to speak and act there."69

When forty members of the Catholic order of the White Fathers decided to leave Mozambique in May 1971 as a sign of protest against the Portuguese colonial regime, Philip A. Potter of the WCC questioned the DM's discreet public attitude. ${ }^{70}$ In his reply, Georges Andrié, secretary of the DM, insisted that no discussion about the position of Protestant churches in Mozambique should be held without the presence of African church members, thereby showing his regard for the IPM's opinion. ${ }^{71}$ In September, the DM's Council set up a study group to define the DM's position and strategy in Southern Africa. In a draft letter to Potter in early 1972, Andrié summarised the results of the study group's reflections; although the DM considered the independence struggle to be justified, its tactics were determined by the need to avoid any action that could lead to retaliation against the IPM and the expulsion of Swiss missionaries from Mozambique. Nevertheless, Andrié considered that direct contacts with

68 Ibid., p. 221.

69 DM position paper, dated October 1970 and entitled, by hand, "racisme", p. 2, Archives of the DM (ADM), Lausanne, Switzerland, ${ }_{1653}$ B, box 182.

70 Letter from Philip A. Potter, wCC, to Juel Nordby, United Methodist Church, and Georges Andrié, Secretary of the DM, 30.07.1971, p. 2, ADM 1829B, box 255; see also Andrié, "Groupe d'étude Afrique australe, Bref historique de la question en ce qui concerne le Mozambique", 19.10.1971, ADM 1653B, box 182. On the role of the White Fathers in late colonial Mozambique, see de Souto, Caetano e o Ocaso do 'Império', pp. 398-402.

Letter from Georges Andrié to Philip A. Potter, 07.08.1971, p. 2, ADM 1829B, box 255. 
FRELIMO members should be cultivated and that humanitarian aid could be granted to the movement. ${ }^{72}$ The archives of the DM do indeed contain proof of material humanitarian support provided by DM members to FRELIMO, but the scope of this assistance is difficult to determine. ${ }^{73}$

While DM leaders in Switzerland reflected on their mission in Southern Africa and Third World solidarity groups protested against the construction of the Cabora Bassa dam, events in Mozambique took a drastic turn. In June 1972, the DM's fears of violent action against African church members were proved to be well-founded when the PIDE/DGS rounded up more than 1,500 Mozambicans suspected of being members of FRELIMO. Around 30 African priests and employees of the Swiss Mission were also detained. Swiss missionaries in Mozambique immediately tried to obtain more information. Although the head of the DGS in Lourenço Marques did not inform them of the actual charges against the arrested men, he assured them that the operation was not directed against the mission itself or against European missionaries. ${ }^{74}$ During a trip to Lourenço Marques in September 1972, two DM representatives were able to visit the majority of the detained IPM members. Several present and former leaders of the IPM were among the prisoners, most famously the sitting President of the Synodal Council, Zedequias Manganhela. He was accused, inter alia, of having met a FRELIMO leader in Switzerland 6 years previously. ${ }^{75}$ The fact that a meeting between Eduardo Mondlane and Manganhela had indeed taken place in July 1966 through the somewhat reluctant intermediary of the DM testifies to the efficiency of Portuguese surveillance. ${ }^{76}$

72 Draft letter from Georges Andrié to Philip A. Potter, o8.02.1972, p. 7, ADM 1829C, Box 255.

73 In 1966, for example, the DM reacted positively to the request of Janet Mondlane, wife of FRELIMo leader Eduardo Mondlane, for primary school books that were to be used in schools set up by the liberation movement: Letter from F. Ouwehand to Janet Mondlane, 07.04.1966, ADM 793E, box 72. In 1973, a DM member sent medications to FRELIMO: Letter from Samuel Rodrigues Dhlakama, head of FRELIMO's health services, to Jean-Paul A. Widmer, DM, 04.07.1973, ADM 1821D, box 254.

74 Letter from Louis Chaney, Swiss consul in Mozambique, to the DPA, "Mission Suisse. Arrestations d'Africains", 27.06.1972, confidential, pp. 1-2, SFA E2200.167\#1991/284\#21*. On the arrests of IPM members, see also Cruz e Silva, Protestant Churches, pp. 138-149; Alf Helgesson, Church, State and People in Mozambique. An Historical Study with Special Emphasis on Methodist Developments in the Inhambane region, Uppsala: Swedish Institute of Missionary Research, 1994, pp. 368-374. On the role of the Portuguese secret service in the colonial war, see Dalila Cabrita Mateus, A PIDE/DGS na Guerra Colonial (1961-1974), Lisbon: Terramar, 2004.

75 Georges Andrié, memorandum, "Communication au Synode missionnaire sur la situation au Mozambique”, 30.11.1972, pp. 1-3, ADM 1862B, box 262.

76 Charles Périer, memorandum, "Entrevue Manganhela - Edwardo Mondlane, en l'absence de M. Ouwehand et M. Vittos, mercredi 13 juillet 1966", no date, ADM $793 \mathrm{E}$, box 72. 
The colonial authorities' fear of the IPM's and the DM's subversive potential is expressed in a report by the Mozambican DGS written in early November 1972 after the DM members' visit: "There are therefore no doubts as to the danger posed, in the political situation of this state, by the subversive action that is being developed by elements of the Swiss Mission, given the great mass of believers that it guides, and given the prestige in which it is held by the natives" ${ }^{77}$ In the second half of 1972, the DM tried ceaselessly to obtain the liberation of its fellow church members. The organisation informed the Swiss public about the fate of the detainees, met with the Swiss ambassador in Lisbon and with Portuguese clerics and members of the DGS in Mozambique, and collaborated with the International Commission of Jurists and Amnesty International. ${ }^{78}$

On 11 December 1972, Manganhela died in prison. The official cause of death was reported to be suicide. Shortly afterwards, the death of another detained IPM member became public. Most of the arrested IPM members were subsequently released, probably on orders from Lisbon. However, the risk to the IPM, the DM, and their members was far from over. Prior to their release, the detainees had been coerced into signing declarations stating that IPM meetings were in truth meetings of FRELIMO and that the church sent money to the liberation movement's headquarters in Dar es Salaam through the intermediary of the DM. Swiss missionaries feared that the DGS would use these declarations to take further action against the IPM and the DM. ${ }^{79}$ In February 1973, missionary Marcel Vonnez, stationed in Beira, reported on the Portuguese accusations: "Each of our services ends with 'Viva o Frelimo!" Manganhela, so rumour had it, had been designated to become the future president of independent Mozambique, and the Swiss Mission his government. At the same time, Vonnez was sure that the Portuguese authorities did not believe in these charges but would use them as a pretext to expel Swiss missionaries, if desired: "What annoys people is the influence of the Swiss Mission on the population." 80

In order to protest the innocence of the liberated prisoners and to refute the accusations made against the DM, the missionary organisation's leadership

77 DGS Mozambique (signature not legible), report, "Prisões efectuadas por esta delegação de segurança de elementos da missão suiça, desta cidade, quando da - operação 'vendaval", o3.11.1972, p. 6, ANTT, PIDE/DGS, CI(2), no 19639.

78 Georges Andrié, memorandum, "Communication au Synode missionnaire sur la situation au Mozambique”, 30.11.1972, pp. 1-4, ADM 1862B, box 262.

79 George Andrié, memorandum, "Situation de l'église presbytérienne au Mozambique", 10.01.1973, strictement confidentiel, p. 2, ADM 1862B, box 262.

8o Letter from Marcel Vonnez, DM missionary in Mozambique, to Georges Andrié, o3.02.1973, p. 2, ADM 1825 D, box 255 . 
intensified its use of diplomatic channels in early 1973. In January, DM members called on the Portuguese ambassador in Bern, Eduardo Bugalho. They were hoping to explain the impact that Manganhela's death had had in Switzerland. ${ }^{81}$ The Portuguese embassy received dozens of identical cards from residents of the French-speaking part of Switzerland protesting against the treatment of IPM members. Lisbon did not find out who was behind this campaign; the DM protesting its innocence. ${ }^{82}$ During a meeting with Federal Councillor Pierre Graber and other FPD leaders in the same month, representatives of the missionary society explained their difficulties in Mozambique. Graber expressed his gratitude for the DM's missionary and humanitarian activities in Mozambique and promised the FPD's support in rejecting the false accusations made against the missionaries. At the same time, he warned the DM, "in view of the tensions prevailing in this Portuguese overseas territory, to avoid, by means of the necessary restraint both in dealing with the authorities and the indigenous population, anything that might appear to be interference in the political confrontation or even partisanship." ${ }^{83}$ In April, Georges Andrié continued the campaign to clear the DM's name with a call on the US consul in Mozambique, probably in the hope of enlisting his aid in case of the expulsion of Swiss missionaries from the Portuguese colony. ${ }^{84}$

The DM-F PD meeting in Bern reveals that the leading Swiss foreign policymakers held the missionary organisation in great esteem and deemed its educational and medical activities a boost to Switzerland's humanitarian image. They relied on missionary organisations such as the DM for their development aid policy and to present Switzerland in a positive light. Thus, in February 1973 the FPD's Secretary General asked Jean-Louis Pahud, Swiss ambassador in Portugal, to discuss the DM's situation informally with the Portuguese authorities

81 Letter from Eduardo Bugalho, Portuguese ambassador in Switzerland, to the Portuguese Minister of Foreign Affairs, "Missão suíça de Moçambique", 23.01.1973, pp. 2-5, ANTT, SSCIM, no 432 .

82 Letter from Angelo Ferreira, director of the Gabinete dos Negócios Políticos (Office of Political Affairs, GNP) in the Portuguese Overseas Ministry, to the Governor-General of Mozambique, 23.02.1973, ANTT, SSCIM, no 432.

83 Hermann Grob, DPA, Michael Gelzer, memorandum, "Notiz über die Besprechung mit der Delegation des "Département missionaire des églises protestantes de Suisse romande" vom 18. Januar 1973", no date, p. 4, attached to the letter from Ernesto Thalmann, Secretary General of the FPD, to Jean-Louis Pahud, Swiss ambassador in Portugal, "Schwierigkeiten der 'Mission Suisse' in Mozambique", o9.02.1973, confidential, sFA E2200.167\#1991/284\#21*.

84 Telegramme no 244 from [?] van Oss, US consulate in Mozambique, to the Secretary of State, 12.04.1973, p. 2, NARA, RG 59, AAD, CFPF, Electronic Telegrams 1973, 1973LOURENoo244. 
and to refute categorically all accusations made against this organisation. ${ }^{85}$ Pahud, who was generally very uncritical of the Estado Novo regime's colonial policy and a staunch supporter of the official Swiss line of non-intervention in the internal affairs of other states, thought less highly of the DM. While he was willing to believe DM's assurance that it had not supported FRELIMO, he wondered if the organisation could really guarantee that its contributions to the IPM had not ended up in the hands of the liberation movement. Convinced that the missionaries' problems were at least partly of their own making, he did not think it advisable to approach the Portuguese authorities on their behalf: "the DM plays with fire in Mozambique and now, suddenly worried, it asks the Political Department for protection against the risk of burns or even flames". ${ }^{86}$ Yet, Pahud was requested in no uncertain terms to do as he was told. ${ }^{87}$ High-ranking members of the Portuguese administration later assured the Swiss ambassador that the missionaries would be allowed to continue their work in Mozambique, if they did not take a political stand. 88

In October 1973, the Council of the DM decided to accede to an appeal from the IPM to request an audience with Marcello Gaetano in order to clear the released Presbyterians' names and free some IPM members that were still imprisoned. ${ }^{89}$ While Michael Gelzer, the deputy chief of the DPA, was not very optimistic about the DM's chances of obtaining an audience, he nevertheless agreed to support the request. At the same time, several lawyers worked on the indictments against the released IPM prisoners in Mozambique. ${ }^{90}$ On 14 November 1973, the Portuguese authorities promulgated an act of amnesty. The charges against the 33 IPM members freed in 1972 were dropped and a further 19 members were freed. ${ }^{91}$ Against the advice of the DPA, whose leaders feared that such an approach would only further antagonise the Portuguese

85 Letter from Ernesto Thalmann to Jean-Louis Pahud, "Schwierigkeiten der 'Mission Suisse' in Mozambique", o9.02.1973, SFA E2200.167\#1991/284\#21*.

86 Letter from Jean-Louis Pahud to the DPA, "Difficultés de la 'Mission Suisse au Mozambique", 05.03.1973, p. 3, SFA E2001E-01\#1987/78\#4610*.

87 Telegram no 17 from the DPA to the Swiss embassy in Portugal, 19.03.1973, SFA E2001E-o1\#1987/78\#4610*.

88 Letter from the Jean-Louis Pahud to the DPA, "Difficultés de la 'Mission Suisse' au Mozambique", 30.03.1973, strictly confidential, SFA E2200.167\#1991/284\#21*.

89 Minutes of the $100^{\text {th }}$ meeting of the DM's Council on 04.10.1973, no date, confidential, pp. 6-7, ADM, folder Conseil 1973-1978.

90 Letter from Michael Gelzer to the Swiss Ambassador in Portugal, "Mission Suisse' in Mozambique", confidential, 17.10.1973, pp. 2-3, SFA E2200.167\#1991/284\#21; letter from Gelzer to the DM, 15.11.1973, confidential, ibid.

91 Letter from Louis Chaney to the DPA, "Mission suisse au Mozambique (Eglise presbytérienne)", 04.12.1973, p. 1, SFA E2200.167\#1991/284\#21*. 
government, the DM persisted in its efforts to meet with Caetano, with success. On 7 February 1974, the Portuguese president received three DM leaders. Caetano assured the delegation that the DM need not worry about its future in Mozambique and that the freed prisoners were safe from further prosecution. Nevertheless, the delegates were frustrated that they were not able to clear Manganhela's name. ${ }^{92}$

For the Swiss government, the activities of the DM missionaries were a potential source of both political goodwill and of tension. Their ambivalent attitude towards Swiss citizens in Portuguese Africa was not restricted to missionaries, as demonstrated by an episode involving a Swiss businessman in Mozambique. In early 1968, a South African entrepreneur living in Lourenço Marques created a so-called 'Goodwill Fund' to support the Portuguese troops fighting in this colony. He appealed to members of the foreign business community in Mozambique to make donations for the purchase of two air ambulances, after an initial plan to buy war materials gave rise to reservations. The director of Swiss import firm Bridler \& Co. was one of the deputy chairmen of the fund's committee, and thereby openly sided with the colonial army. The Swiss consul cautioned the businessman to minimise his involvement and to ensure that the donations were used for purely humanitarian purposes, warning that FRELIMO might otherwise take retaliatory measures against the committee members. The DPA, which endorsed this recommendation, feared that Switzerland's image might be damaged if it became associated with an organisation that was supportive of Portugal's colonial wars. ${ }^{93}$ Bern's attitude corresponded to that of the US government; the American consul voiced similar reservations with regard to the engagement of American citizens in the Goodwill Fund. ${ }^{94}$ The DPA preferred Swiss citizens living in Africa to keep a low profile, cause no embarrassment, and boost Switzerland's image by doing their work well, be it business or missionary activity.

92 Georges Andrié, memorandum, “Compte-rendu approximatif de l'entrevue accordée par le Prof. Marcello Caetano, Premier ministre à MM. G. Guinand, G. Morier-Genoud, G. Andrié, au palais de Sao Bento - à 17 heures", 07.02.1974, ADM 1862C, box 262; letter from Jean-Louis Pahud to the DPA, "Mission Suisse au Mozambique", o8.o2.1974, confidential, SFA E2001E-01\#1987/78\#4610*.

93 Letter from Jakob Etter, Swiss consul in Mozambique, to the DPA, "Gründung eines 'Goodwill Fund' der hiesigen ausländischen Kolonie zu Gunsten der in Moçambique eingesetzten Soldaten", 22.05.1968, SFA E2001E\#1980/83\#3788*; see also the letter from Jacques-Bernard Rüedi to the Swiss consulate in Mozambique, "Goodwill Fund", 04.06.1968, ibid.

94 Airgram from J. G. Gossett, US Consul-General in Mozambique, to the Department of State, "Goodwill Fund of Mozambique's Foreign Communities, 04.06.1968, NARA, RG 59, Subject-Numeric Files 1967-1969, POL 15 MOZ, box 2353. 
In Angola, there was no such trouble. Protestant Swiss missionaries seem to have come to an arrangement with the Estado Novo regime. In July 1973, Marcello Caetano most courteously received the leader of the Mission philafricaine, Dr. Rodolphe Bréchet. ${ }^{95}$ Bréchet assured the DPA in early 1974 that the work of his mission proceeded unhindered and in fact received much support from the Portuguese authorities. This he explained by his organisation's abstention from all political activities and the fact that the missionaries were mindful of the Portuguese colonial authorities in Angola, which they considered their hosts. ${ }^{96}$ There are no signs that the Mission philafricaine ever criticised Portugal's colonial policy.

Thanks to the DM's incessant lobbying for the liberation of the members of its African sister church, religious circles in French-speaking Switzerland were well informed about the arrests, and Manganhela's death in late 1972 caused a wave of indignation. This explains why churches were some of the first actors to mobilise against Portugal's invitation to a major Swiss trade fair in 1973 as a guest of honour.

\section{Economic Interests vs Human Rights: Portugal's Invitation to the 1973 Comptoir Suisse Trade Fair}

The year 1973 marked the high point of Swiss protests against Portuguese colonialism and Switzerland's role in the independence wars in Angola, Mozambique, and Guinea-Bissau. In September, several thousand people marched in Lausanne to express their objection to Portugal's colonial policy. Demonstrators stormed the exhibition grounds of the Comptoir Suisse, a major Swiss trade fair to which Portugal was invited as a guest of honour. Violent clashes with the police led to the arrest and charging of many demonstrators. Observers considered this demonstration to be atypical of Switzerland's political scene. It was preceded by several months of intensive lobbying by a broad coalition of religious and solidarity actors that urged the fair's organisers and the Swiss government to rescind the invitation to Portugal. This was one of the few instances in the late 196os and 1970s where the Federal Council as a whole discussed Switzerland's position on Portuguese colonialism.

95 Letter from Michael Gelzer to the DM, 15.11.1973, confidential, p. 3, SFA E2200.167\#1991/ $284 \# 21^{*}$.

96 Alfred Hohl, DPA, memorandum, "Vorsprache Dr. Bréchet bei Botschafter Thalmann", 18.02.1974, p. 2, SFA E2001E-o1\#1987/78\#4650*. 
Portugal's invitation to the Comptoir Suisse initially mobilised religious circles. In early 1973, the EvB and the Africa Institute in Geneva contacted the organisers of the fair and expressed their reservations about the invitation. In April, an article in the Protestant weekly journal La Vie Protestante taking up the same point compelled the fair's organisers to take a stand. Marc-Antoine Muret, General Secretary of the Comptoir Suisse, explained to the daily newspaper 24 Heures that the invitation had been extended in consultation with the federal authorities and that ideological considerations did not influence the choice of guests. Several Swiss newspapers recounted this exchange.${ }^{97}$ It is likely that the DM, which was at that time busy trying to obtain the liberation of Mozambican Christians, initiated this first controversy. In March 1973, the missionary organisation's Council had decided to inform other churches of French-speaking Switzerland about Portugal's invitation to the Comptoir Suisse and urge them to take a stand. ${ }^{98}$

As the appeal to the fair's organisers did not achieve the desired results, several churches and religious groups addressed their concern to the Swiss government in May and June 1973. They criticised the Estado Novo regime's colonial policy, especially its treatment of the IPM members, and warned of possible demonstrations if the invitation were upheld. ${ }^{99}$ It may seem surprising that these groups asked the Federal Council to intervene in a privately organised economic event. However, the Swiss authorities and the fair's organisers collaborated closely; the Swiss government was officially represented at the Comptoir Suisse and the DPF was consulted about the choice of the three

97 See the letter from Eduardo Bugalho to the Portuguese Foreign Minister, "Comptoir de Lausanne", 16.04.1973, AHD, PAA, pr. 922, box 1226, and attached newspaper articles: MS, "Portugal bleibt Ehrengast des 'Comptoir", Tages-Anzeiger, 11.04.1973; PLR, "Proteste gegen Ehrengast Portugal am Comptoir Suisse. 'Keine ideologische Rücksicht”, National Zeitung, 11.04.1973; letter from Bugalho to the Foreign Minister, "Comptoir de Lausanne", 24.04.1973, ibid., and attached news items: ATs-ssp, "Au Comptoir de Lausanne. Etait-il opportune d'inviter le Portugal?” La Suisse, 11.04.1973; ATs, “Quels hôtes pour le Comptoir? L'invitation faite au Portugal soulève la polémique”, Gazette de Lausanne, 11.04.1973.

98 Minutes of the $95^{\text {th }}$ meeting of the DM's Council on 24 March 1973, confidential, p. 2, ADM, folder Council 1973-1978.

99 Letter from Guy-Olivier Segond and Jean-Pierre Jornod, Protestant Church of Geneva, to Pierre Graber, Federal Councillor and head of the FPD, 18.05.1973, SFA E2001E-o1\#1987/78\#884*, see also the attached letter from Segond and Jornod to the director of the Comptoir Suisse, 08.05.1973; Hermann Grob, "Notiz über die Besprechung mit der Delegation des 'Département missionnaire des églises protestantes de la Suisse romande' (D.m.) vom 6. Juni 1973", o8.o6.1973, confidential, p. 3, ibid.; W. Sigrist, President of the SEK, to Pierre Graber, "Portugal am Comptoir Suisse", o8.o6.1973, ibid. 
annual guests of honour. ${ }^{100}$ Although this did not become public at the time, the invitation to Portugal had even been extended by a Swiss diplomat and was linked to bilateral commercial negotiations. In early 1971, the Fédération Horlogère Suisse (Swiss Watchmakers' Federation, FH) had suggested Portugal's invitation as a sign of Swiss goodwill after the Portuguese government ceded to Swiss demands to abolish tariffs on watches and their components. ${ }^{101}$ In reply to the churches, FPD leaders underlined that Portugal's invitation was justified on economic grounds and that this commercial fair was not the right occasion to discuss political problems. ${ }^{102}$ In June 1973, National Councillor Jean Ziegler also took up the issue and asked the Federal Council to withdraw its official support of the fair. ${ }^{103}$ Shortly afterwards, an international scandal provided further fuel for the protest.

In July 1973, newspaper reports about a massacre committed by Portuguese troops in the Mozambican village of Wiriyamu caused a surge of national and international protest. On 10 July, a few days before Marcello Caetano was scheduled to travel to London for a state visit, The Times published an article by missionary Adrian Hastings about the brutal murder of 400 villagers the previous December. Although Lisbon immediately denied the allegations, the reports of Portuguese atrocities confirmed to many the brutality of the colonial power's repression of Mozambicans suspected of nationalist sympathies. ${ }^{104}$

100 See Ernesto Thalmann, memorandum, "Entretien du 3 août 1973 à Berne entre le Secrétaire général du Département et M. Marc-Antoine Muret, Directeur général du Comptoir Suisse", o6.o8.1973, p. 3, SFA E2001E-01\#1987/78\#884*.

101 Letter from Gerard Bauer, FH President, and René Retornaz, FH Director, to Pierre Languetin, Delegate of the Federal Council for Trade Agreements, "Portugal: importation en suisse de vins fins", 19.04.1971, SFA E7110\#1982/108\#912*. See also the letter from Languetin to Ch. M. Wittwer, General Manager of the Chambre suisse de l'horlogerie (Swiss Chamber of Watchmaking, CSH), and René Retornaz, "Portugal - Problème horloger", 23.03.1971, SFA E7110\#1982/108\#909*, letter from Jean-Louis Pahud to the Trade Division, "Portugal Affaire des vins de qualité", o9.08.1971, p. 2, SFA E7110\#1982/108\#912*.

102 Letter from Jean Zwahlen, head of the FPD's Financial and Economic Service, to the Protestant Church of Geneva, "Participation du Portugal au Comptoir Suisse 1973", 12.06.1973, SFA E20o1E-o1\#1987/78\#884*; letter from Ernesto Thalmann to the SEK, "Teilnahme Portugals am Comptoir 1973", 11.07.1973, ibid.

103 "Petite question Ziegler du 27 juin 1973. Schweizer Comptoir - Comptoir Suisse 1973", Amtliches Bulletin der Bundesverfassung 1973, Herbstsession Nationalrat, o3.10.1973, p. 1391 .

104 Although most scholars agree now that the massacre took place, there is still some debate about its extent. See Bruno Cardoso Reis, Pedro Aires Oliveira, "Cutting Heads or Winning Hearts: Late Colonial Portuguese Counterinsugency and the Wiriyamu Massacre of 1972", Civil Wars 14:1 (2012), pp. 80-103; Mustafah Dhada, "The Wiriyamu Massacre of 1972: Its 
In Switzerland, Hastings's article had an immediate effect. Only a day after its publication, representatives of the Christian Peace Service, the EvB, Action Portugal et Afrique Australe (Operation Portugal and Southern Africa, APAA), the Swiss Human Rights League, the KSA, and the $\mathrm{AG}_{3} \mathrm{~W}$ addressed a telegram to Federal Councillor Pierre Graber. They urged him to convince the organisers of the Comptoir Suisse to withdraw the invitation to "Portugal, which is charged with war crimes", stating: "we consider that Switzerland's image is harmed if a state involved in a colonial war is welcomed to Switzerland as a guest of honour". ${ }^{105}$ According to Gillian G. Brown of the British embassy in Bern, the signatories were "basically respectable organisations though containing individual communists among their members." ${ }^{106}$ In the middle of 1973, the embassy closely observed the activities of Swiss solidarity groups, probably because the British authorities had themselves been confronted with considerable public protest against Caetano's state visit. ${ }^{107}$

A few days after the Wiriyamu massacre became public, the Dutch ambassador in Bern asked the DPA if Bern would be willing to participate in a joint proposal to the Portuguese government to accept an international enquiry into the allegations. DPA leaders decided, however, that Switzerland could not participate in such a step because of the principle of non-interference. ${ }^{108}$ The Swedish government was more outspoken. It heavily criticised the Portuguese government, intended to raise the issue at the UNGA and at a meeting of Nordic

Context, Genesis, and Revelation", History in Africa 40 (2013), pp. 45-75; Mustafah Dhada, "The Wiriyamu Massacre of 1972: Response to Reis and Oliveira, Civil Wars 15:4 (2013), pp. 551-558; Bruno Cardoso Reis, Pedro Aires Oliveira, "Reply to Mustafah Dhada", Civil Wars 15:4 (2013), pp. 559-562; Mustafah Dhada, The Portuguese Massacre of Wiriyamu in Colonial Mozambique, 1964-2013, London et al.: Bloomsbury, 2016. On Caetano's state visit to London, see Norrie MacQueen, Pedro Aires Oliveira, “'Grocer meets Butcher': Marcello Caetano's London Visit of 1973 and the Last Days of Portugal's Estado Novo", Cold War History 10:1 (2010), pp. 29-50.

105 Telegram from the Christian Peace Service (Hansjürg Braunschweig, Peter Rüegg), EvB (Georges Rossier, Annemarie Holenstein, François de Vargas), APAA (Dyons Gerard, Jacky Corthay), Swiss Human Rights League (Joan Chicherio), KsA (Daniel Kohn), AG3W (Andres Anderli) to Pierre Graber, 11.07.1973, SFA E2001E-o1\#1987/78\#4651*.

106 Letter from Gillian G. Brown, British Embassy in Bern, to the CSAD, "Mozambique", 16.07.1973, TNA FCO 45/1311.

107 Letter from C.K. Woodfield, UK embassy in Bern, to the CSAD, "Mozambique", o3.08.1973, TNA FCO 45/1313; letter from C.K. Woodfield to the CSAD, "Mozambique”, 13.08.1973, ibid.

108 Handwritten notes by Jean-Jacques Indermühle, DPA, dated 17.07.1973 about his discussion with Ernesto Thalmann and Michael Gelzer, on Jean-Jacques Indermühle, memorandum, "Entretien téléphonique avec M. Kist, Conseiller de l'Ambassade des Pays-Bas", 16.07.1973, p. 1, SFA E2Oo1E-o1\#1987/78\#4651*. 
Ministers, and doubled its aid to FrELIMo. ${ }^{109}$ The Danish government also vocally condemned the massacres and seconded the Swedish UN initiative.110

Faced with renewed demands to rescind Portugal's invitation to the Comptoir Suisse, the Swiss government prevaricated. DPA members asked Switzerland's diplomatic posts in Lisbon and Lourenço Marques for more information. Consul Louis Chaney in Mozambique was quite objective. He underlined that, as long as the Portuguese authorities refused an international enquiry, there was not sufficient information available to conclusively prove or disprove the massacre claims. ${ }^{111}$ Ambassador Jean-Louis Pahud in Lisbon was staunchly pro-Portuguese. He argued that withdrawing the invitation "would amount to bringing the Government of Lisbon to trial on the basis of accusations made without any proof by a media outlet in the context of an internal policy manoeuvre of a third state" and warned that the Portuguese government would react strongly to such interference. ${ }^{112}$ The Portuguese authorities indeed observed the events in Switzerland closely for any sign of a change in attitude from the Federal Council or the organisers of the fair. But in mid-July 1973, the latter only suggested that, in order to mitigate possible attacks during the Comptoir Suisse, the Portuguese authorities should limit their exposition to commercial issues and avoid any political aspects liable to give rise to controversy. ${ }^{113}$

Protest against Portugal's presence at the trade fair did not die down. The extreme Left picked up the issue and a number of small solidarity movements were created in this context. ${ }^{114}$ In late July 1973, 118 Swiss citizens sent an appeal to the Federal Council, expressing their outrage at the massacres and urging the government to take a stand. Among the signatories were several parliamentarians, professors, and priests, as well as leaders of solidarity movements

109 PR no 6 from Claude Ochsenbein, chargé a.i. Swiss Embassy in Sweden, "Massacres au Portugal - Réactions de la Suède", 17.07.1973, p. 1, SFA E20o1E-o1\#1987/78\#4651*.

110 Letter from Walter Jäggi, Swiss ambassador in Denmark, to the DPA, "Tensions entre le Danemark et le Portugal", 24.07.1973, p. 1, SFA E2001E-o1\#1987/78\#4651*.

111 Letter from Louis Chaney to the DPA, "Manifestation contre les allégations de Massacre au Mozambique", 17.07.1973, confidential, SFA E20o1E-o1\#1987/78\#4651*; letter from Chaney to the DPA, "Situation au Mozambique à la suite des allégations de massacre par l'armée portugaise", 26.07.1973, confidential, ibid., letter from Chaney to the DPA, "Ironie de la guerre et chronique des allégations de massacre par l'armée portugaise au Mozambique", 14.08.1973, ibid.

112 Letter from Jean-Louis Pahud to the DPA, "Massacre au Mozambique?" 23.07.1973, confidential, p. 3, SFA E2001E-01\#1987/78\#4651*.

113 Telegram no. 32 from [?] Lopes Vieira, Portuguese embassy in Switzerland, to the MNE, 20.07.1973, AHD, PAA, pr. 922, box 1226.

114 Pereira, Anti-impérialisme et nouvelle gauche radicale, pp. 77-78. 
and labour unions. ${ }^{115}$ Members of the Christian Peace Service expressed their discontent about the delay in the government's reply to Ziegler's parliamentary question in a letter to the FPD in early August. If the official silence was not broken soon, they argued:

this could not be justified with Swiss neutrality, but would have to be considered a statement in favour of the Portuguese colonial regime. In the case of Portugal at the Comptoir Suisse, the competent authorities in Bern and Lausanne cannot avoid choosing between the colonial power Portugal and the liberation movement FRELIMO, which means, from a political and economic point of view, choosing between the present and the future. ${ }^{116}$

Unknown to the protesting civil society actors, the decision to uphold the invitation to Portugal had already been taken at the highest political level on 3 August 1973. Two weeks earlier, Georges-André Chevallaz, the liberal mayor of Lausanne and future Federal Councillor, had suggested that the FPD should contact Lisbon and explain the problems that the Portuguese presence at the trade fair might cause, notably the risk of violent demonstrations. ${ }^{117}$ As the event was fast approaching and he considered it inadvisable for the FPD to take sole responsibility, the department's Secretary General, Ernesto Thalmann, suggested that Chevallaz's and Ziegler's requests be submitted to the Federal Council. ${ }^{118}$ The draft proposal that he presented to Pierre Graber for approval reflected the shared opinion of the FPD and the Trade Division that the invitation to Portugal should be honoured, as a matter of principle, as well as for reasons of foreign policy: "the cancellation of the invitation at the last moment would be even more detrimental to our international image and our relations with Portugal than the demonstrations that might take place."119 Pierre Graber, however, did not agree with his department. To him, the position of different churches and religious bodies was crucial:

115 Appeal by 118 citizens to the Federal Council, no date, but receipt stamp 30.07.1973, SFA E2001E-o1\#1987/78\#4651*.

116 Letter from Hansjörg Braunschweig and Peter Rüegg, Christian Peace Service, on behalf of the signatories of the telegram of 11 July to Ernesto Thalmann, 08.08.1973, p. 2, SFA E2001E-o1\#1987/78\#884*.

117 Letter from Georges-André Chevallaz, mayor of Lausanne, to Pierre Graber, 19.07.1973, p. 1-2, SFA E2OO1E-01\#1987/78\#884*.

118 Letter from Ernesto Thalmann to Pierre Graber, 20.07.1973, p. 1, dodis.ch/3839o.

119 FPD, draft proposal to the Federal Council, "Portugal, hôte d'honneur du Comptoir Suisse 1973", no date, attached to the note from Ernesto Thalmann to the Federal Council, 27.07.1973, SFA E2OO1E-01\#1987/78\#884*. 
while I attach little importance to most of the organisations that signed the joint telegram to the Political Department, I would consider it very unfortunate to ignore the position of organisations such as the Federation of Swiss Protestant Churches, the Protestant Church of Geneva, and the DM in Lausanne. I cannot help thinking that we badly need the active support of these institutions, and others like them, to back our humanitarian policy in general and development cooperation in particular. ${ }^{120}$

In this, Graber was isolated in the Federal Council. In a telephone meeting on 3 August 1973, the Swiss government decided not to withdraw the invitation. Even the liberal Nello Celio, who had been greatly impressed by the international campaign following the massacre in Mozambique, rallied behind the majority. ${ }^{121}$

Marc-Antoine Muret of the Comptoir Suisse was satisfied with the Federal Council's decision. During a meeting with FPD representatives in Bern, he agreed to cover up the fact that a Swiss diplomat had extended the invitation to Portugal and to publicly declare that it had been made by the organisers of the fair themselves. ${ }^{122}$ The Swiss government's long silence had created tensions with the Portuguese ambassador in Bern. On the day before the Federal Council's decision, Ernesto Thalmann had summoned Eduardo Bugalho at the request of several Federal Councillors. The Secretary General informed Bugalho of the complaints against Portugal's presence at the trade fair, stating clearly, however, that he did not want to exert any pressure on Lisbon to withdraw. ${ }^{23}$ Bugalho was more unsettled than reassured by this conversation, uncertain whether the summons was a veiled attempt at discouraging Portugal's participation. ${ }^{124}$

On 10 August 1973, the Swiss government finally took an official stand and prioritised economic interests over human rights. In its published reply to Ziegler's question, the Federal Council argued that Portugal had been invited, by

120 Letter from Pierre Graber to Ernesto Thalmann, 24.07.1973, pp. 1-2, attached to the note from Thalmann to the members of the Federal Council, 27.07.1973, SFA E2001E-o1\#1987/ $78 \# 884^{*}$.

121 Excerpt of the minutes of the 5 th extraordinary meeting of the Federal Council on 3 August 1973, "Portugal als Ehrengast am Comptoir Suisse", 03.08.1973, p. 2, dodis.ch/30305.

122 Ernesto Thalmann, memorandum, "Entretien du 3 août 1973 à Berne entre le Secrétaire général du Département et M. Marc-Antoine Muret, Directeur général du Comptoir Suisse", o6.08.1973, p. 3, SFA E2001E-o1\#1987/78\#884*.

123 Note from Ernesto Thalmann to the members of the Federal Council, 02.08.1973, SFA E2001E-o1\#1987/78\#884*.

124 Telegram no. 36 from Eduardo Bugalho to the MNE, 02.08.1973, urgent, confidential, AHD, PAA, pr. 922, box 1226; see also telegram no. 38 from Eduardo Bugalho to the MNE, 07.08.1973, ibid. 
the Comptoir Suisse, for entirely economic reasons and that it would be premature to rescind the invitation in the absence of objective information about the massacre allegations. Finally, the Federal Council underlined its firm intention to be officially represented at the fair due to the event's importance for the Swiss economy and the fact that Switzerland enjoyed normal diplomatic relations with its fellow EFTA member. ${ }^{125}$ This reply reassured Swiss business people in Lisbon, who had feared that anti-Portuguese sentiments in Switzerland might endanger their interests. ${ }^{26}$

On the evening before the publication of the Federal Council's reply, Chevallaz's letter was mentioned on television. Speculation about the mayor's take on Portugal's invitation created a sensation in the press and almost caused a diplomatic incident. After receiving a worried early morning phone call from Eduardo Bugalho, Charles Müller, deputy chief of the DPA and head of its European Division, invited the Portuguese ambassador to the FPD to inform him personally of the Federal Council's reply to Ziegler's question. ${ }^{127}$ Bugalho, who was still not sure of the Swiss authorities' real intentions, let himself finally be persuaded that the Federal Council did not intend to hint that the Portuguese should reconsider coming to Switzerland. ${ }^{28}$ The head of the Trade Division, Paul Rudolf Jolles, also tried to reassure the ambassador and to dispel any ill feeling that might be caused by the Federal Council's reply.129

With the publication of the Federal Council's reply to Ziegler's question, Portugal's presence at the Comptoir Suisse was confirmed. A number of Protestant and Catholic organisations continued to lobby the government. ${ }^{130}$ Other, more radical groups came together to form a joint committee in order to coordinate a campaign that focused on the fight against Portuguese colonialism and support for liberation movements, the denunciation of Portuguese oppression in the metropolis, and the complicity of Swiss political and economic elites with

125 "Petite question Ziegler du 27 juin 1973. Schweizer Comptoir - Comptoir Suisse 1973. Réponse du Conseil federal du 10 août 1973", Amtliches Bulletin der Bundesverfassung 1973, Herbstsession Nationalrat, 03.10.1973, p. 1391.

126 See telegram no 32 from Jean-Louis Pahud to the DPF, 10.08.1973, SFA E20o1E-o1\#1987/ $78 \# 4651^{*}$.

127 Charles Müller, Deputy Chief of the DPA, memorandum, "Beteiligung Portugals am Comptoir Suisse 1973", 10.08.1973, SFA E2001E-01\#1987/78\#884*.

128 Telegram no 43 from Eduardo Bugalho to the MNE, 13.08.1973, AHD, PEA, pr. 331.80, box 756.

129 Telegram no 41 (42) from Eduardo Bugalho to the MNE, 13.08.1973, p. 2, AHD, PEA, pr. 331.8 o, box 756 .

130 Letter from W. Sigrist and W. Probst to Pierre Graber, "Teilnahme Portugals am Comptoir 1973", 20.08.1973, SFA E2001E-o1\#1987/78\#883*; letter from André Gachet, on behalf of Protestant and Catholic working groups in Geneva, to Swiss President Roger Bonvin, 04.09.1973, p. 1, SFA E2OO1E-o1\#1987/78\#884*. 
the Estado Novo regime. They prepared leaflets to be distributed at the entrance to the trade fair, organised counter-expositions in many cities in French-speaking Switzerland, and called for a demonstration in Lausanne against Portugal's presence at the Comptoir. The APAA, a religiously motivated Third World solidarity group founded in the run-up of the trade fair, seems to have played a particularly important role. ${ }^{131}$ The day before the opening of the fair, the Bishop of Fribourg, Lausanne, and Geneva further increased tensions by officially refusing to accept an invitation to the Comptoir Suisse. As he wrote in a communiqué, he feared that participating in this event, "could, in the present context, be interpreted as an act of solidarity with the injustices committed in certain Portuguese colonies against the indigenous population as well as against Catholic and Protestant missionaries".132

On 8 September 1973, the opening day of the Comptoir Suisse, several thousand people participated in a protest march towards the exhibition grounds, making it, according to historian Nuno Pereira, one of the most spectacular events of the post-1968 protest cycle in Switzerland. ${ }^{133}$ When demonstrators tried to occupy the Portuguese exhibition, there were violent clashes with the police; many people were arrested and about fifty charged with rioting. The demonstrators were not discouraged and continued their activities two days later, on Portugal's official day at the fair. Pamphlets distributed on this occasion by the APAA claimed that, "[ $t$ ]he Comptoir is not neutral: it does not invite the Portuguese people, but the Portugal of dictatorship and colonial terror", 134 and condemned repression by the Swiss government and police:

We do not want this democracy, where a minority is in power, which seeks to muzzle the protesters in order to maintain silence about the exploitation that the Portuguese people and the African peoples are fighting and to deflect attention away from the fact that large Swiss companies benefit

See D. Muller, Gerard Dyens, APAA, (eds.), pamphlet, "Contre le terrorisme portugais: soutien aux mouvements de libération", no date [before 8 September 1973], p. 2, attached to the letter from the director of the GNP to the General Director of Security, 22.11.1973, ANTT, PIDE/DGs, Cl(2), no 129o/73, NT 7872. On the APAA, see Pereira, Anti-impérialisme et nouvelle gauche radicale, pp. 169-170.

132 Chancellery of the diocese of Fribourg, 07.09.1973, cited in telegram no 56 from Eduardo Bugalho to the MNE, 07.09.1973, AHD, PEA, pr. 331.80, box $75^{6}$.

133 Pereira, "Le mouvement suisse de 1968", pp. 152-153.

134 D. Muller, Gerard Dyens, APAA, (eds.), pamphlet, "Contre le terrorisme portugais: soutien aux mouvements de libération", no date [before 8 September 1973], p. 5, attached to the letter from the director of the GNP to the General Director of Security, 22.11.1973, ANTT, PIDE/DGS, Cl(2), no 129o/73, NT 7872 . 
from this exploitation, by building their factories in Portugal and paying a pittance to the workers. ${ }^{135}$

This proved to be the high point of Swiss protest against Portugal at the Comptoir Suisse. On 11 September 1973, the Chilean coup d'état made international headlines and diverted the attention of many Swiss solidarity movements away from the trade fair in Lausanne.

The demonstration and lobbying against Portugal's presence at the Comptoir Suisse was noted and commented upon by the ambassadors of several other countries. The Finnish ambassador to Switzerland and Portugal told his US colleague in Lisbon that the incident was "particularly noteworthy as indicating that anti-Portuguese sentiment [was] spreading even among generally politically apathetic Swiss."136 The US ambassador in Bern, however, thought that Portugal had simply been a "convenient target" for the "very well-organized but small radical-Left minority movement in Switzerland which, deprived of VietNam as an issue, has needed some sort of focal point around which to rally its followers and keep them motivated"137 and that it should not be considered an indication of the feeling of the general Swiss public. The account of the demonstration by the British embassy in Bern was more factual, underlining that opposition to Portugal's presence in Lausanne was mainly concentrated in leftist circles. ${ }^{138}$

On a bilateral level, the demonstrations did not disturb diplomatic relations between Switzerland and Portugal. As was customary, the Swiss president and high-ranking FPD representatives visited the Portuguese exhibition, and conversations with the Portuguese ambassador at the official dinner focused on economic affairs. ${ }^{139}$ Switzerland's representatives in Portugal and Mozambique confirmed that the events in Lausanne had not led to a deterioration of rela-

135 J. M. Cruchet (ed.) for the joint committee against Portugal's presence at the Comptoir and the schoolchildren's committee against Portugal's presence at the Comptoir, "Laction contre la présence du Portugal au Comptoir se poursuit", [10.09.1973], p. 1, attached to the letter from the director of the GNP to the General Director of Security, 22.11.1973, ANTT, PIDE/DGS, Cl(2), no 129o/73, NT 7872 .

136 Cited in the telegram from [?] Post, US Embassy in Portugal, to the US Embassy in Switzerland, o3.10.1973, NARA, RG 59, AAD, CFPF, Electronic Telegrams 1973, 1973LISBONo3637.

137 Telegram from Shelby Cullom Davis, US ambassador in Switzerland, to the US Embassy in Portugal, 11.10.1973, NARA RG 59, Subject-Numeric Files 1970-1973, POL 23-8 SWITZ, box 2612.

138 Letter from C.K. Woodfield, UK embassy in Bern, to the CSAD, "Mozambique", 19.o9.1973, TNA FCO $45 / 1314$.

139 Telegram no 57 from Eduardo Bugalho to the MNE, 14.09.1973, AHD, PEA, pr. 331.80, box 756. 
tions with the Estado Novo regime. ${ }^{140}$ While solidarity movements continued to sporadically demand that the Swiss authorities take a stand on Portugal's colonial policy and the massacre claims up until the Carnation Revolution, public attention died down after the Comptoir Suisse closed its doors.

The demonstration against the Portuguese presence at the Comptoir Suisse was the culmination of several years of Swiss protest against Portuguese colonial rule and what was considered to be the Swiss government's complicity with this imperialist regime. The high level of protest activities in Switzerland was down to the interplay of national and international factors. The Bührle scandal of 1968 exposed the contradictions between humanitarian aid and arms exports to the Third World. The use of Swiss-made guns during the Biafra War appalled large parts of the Swiss population and drew their attention to the country's Africa policy. The transnational campaign against the Cabora Bassa dam in Mozambique in the early 1970 s was another important focal point for Swiss civil society actors. They took up the criticism of Western collaboration with the Portuguese colonial regime voiced by FRELIMO and solidarity movements in other European states and applied it to the national context, in particular to ввС's indirect participation in the dam's construction. The imprisonment and death of IPM members in Mozambique in 1972 alarmed religious circles in Switzerland and convinced them of the oppressive nature of the Portuguese colonial regime. Then, reports of the Wiriyamu massacre in the international press in July 1973 further fuelled Swiss protests. Finally, and most importantly, the invitation of Portugal as a guest of honour to a Swiss trade fair provided an ideal rallying point, as it exposed the cordial relations of Swiss business elites and the government with the Estado Novo regime.

Swiss non-state actors' material assistance of liberation movements in Angola and Mozambique seems to have been limited. There are few signs that solidarity movements prevented Swiss firms from trading with and investing in the Portuguese colonies and they did not succeed in convincing the Swiss government to publicly take a stand against Portuguese colonialism. Nevertheless, the heterogeneous Swiss solidarity movement was a political force in the late 196os and early 1970s. It helped delegitimise Portuguese colonialism, made economic collaboration a subject of discussion, and forced firms like ввс Baden to publicly justify their position. Swiss non-state actors closely scrutinised their government's Africa policy and their frequent appeals put Bern on the defensive. The criticism of churches and missionary organisations was particularly difficult to rebut.

140 Letter from Louis Chaney to the DPA, 17.09.1973, SFA E2001E-01\#1987/78\#884*; letter from Bruno Stöckli, chargé d'affaires a.i. of the Swiss Embassy in Portugal, "Demonstration gegen Portugal anlässlich des Comptoir Suisse", 20.o9.1973, ibid. 